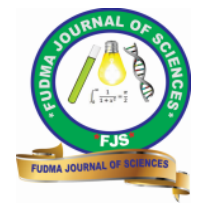

FUDMA Journal of Sciences (FJS)

ISSN online: $2616-1370$

ISSN print: 2645 - 2944

Vol. 4 No. 3, September, 2020, pp $609-614$

DOI: https://doi.org/10.33003/fjs-2020-0403-426

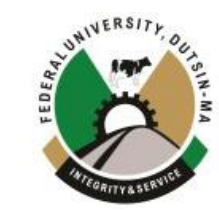

\title{
DIMENSIONAL STABILITY AND TENSILE STRENGTH OF WOOD PLASTIC COMPOSITE FORMED WITH HIGHER PLASTIC CONTENT
}

\author{
${ }^{* 1}$ Lawal, K. J., ${ }^{1}$ Oluyege, A., ${ }^{3}$ Bola, T. S., ${ }^{2}$ Aina, K. S., ${ }^{2}$ Falemara, B. C., ${ }^{4}$ Gakenou, O. F. \\ ${ }^{1}$ Department of Forestry and Wood Technology, Federal University of Technology, Akure, Ondo State, Nigeria \\ ${ }^{2}$ Research Coordinating Unit, Forestry Research Institute of Nigeria, Ibadan, Oyo State, Nigeria \\ ${ }^{3}$ Department of Forest Resource Management, University of British Columbia, Vancouver, Canada \\ ${ }^{4}$ Department of Forestry and Wildlife Management, Federal University of Agriculture Abeokuta, Ogun State, Nigeria \\ *Corresponding Author’s Email: lawalkudirat95@gmail.com,+234-8142618926
}

\begin{abstract}
This study investigated the dimensional stability and strength properties of plastic bonded composites produced from wood waste particles and polyethylene using extruder. The composites were produced from wood species such as such as: Triplochiton scleroxylon, Terminalia superba and Gmelina arborea at a mixing proportion of 60:40 (plastic/wood) on a weight by weight basis. Evaluation of properties was carried out in accordance with the American Standard Testing Methods of 570 and 790 to determine the dimensional stability and strength properties of the composites. The results of findings revealed that water absorption and thickness swelling of the wood composites ranged from $10.08 \%$ to $15.36 \%$ and $4.33 \%$ to $5.58 \%$ respectively after 24 hours and 48 hours immersion in water. Tensile strength also ranged between $29.4 \mathrm{MPa}$ and $45.6 \mathrm{MPa}$. Composite board made from T. superba wood particles had the lowest significant water absorption (10.08\%), thickness swelling (4.33\%) and highest significant tensile strength (45.6MPa) compared to composites produced from G. arborea and T. scleroxylon wood particles. It was observed that high density wood species exhibit lower water intake, lower thickness swelling and higher tensile strength, while the contrary is the case for lower density wood species. In conclusion, the three tree species used for the study could be recommended for the production of wood composite like particle board, fibre board, wood cement boards and others.
\end{abstract}

Keywords: Composites, Density, Dimensional stability, Polyethylene, Strength properties, Wood wastes.

\section{INTRODUCTION}

Enormous volume of wastes that could be harnessed to produce value added products are generated by the wood processing industries (Akhator et al., 2017). These wastes are usually generated from the forest, sawmill, plywood mill, particleboard mill, furniture industry etc. (Akhator et al., 2017). However, the huge volumes of these wood wastes are usually discarded indiscriminately due to poor disposal and management systems, thus constituting various environmental nuisance and health problems which also contribute to climate change issues. Olufemi et al., (2012) opined that land fill disposal and burning of wood residues are becoming less acceptable, hence there is need to find economic use for these residues. The same goes for plastics as a pollutant which accumulates in the environment because it degrades very slowly. According to Geyer et al. (2017), 8.3 billion metric tons of plastics was generated by humans in 2015, 6.3 billion tons had already become waste while $9 \%$ was recycled, $12 \%$ was incinerated and $79 \%$ accumulated in landfills or the natural environment such as streams, rivers and canals which leads to the blockage of drainage systems which lead to flooding and land degradation.

The various forms of plastics include Polyethylene terephthalate (PET), High density polyethylene (HDPE), Plasticized Polyvinyl chloride (PVC-P), Low density polyethylene (LDPE), Polypropylene (PP), Polystyrene (PS) and Expanded polystyrene (EP) (UN 2018, Alabi 2019).
However, the indiscriminate wastes (both wood and plastic) disposal methods negates the 2030 agenda for sustainable development, particularly goal 11, 12 and 15 on solid waste management, sustainable development and management (Pianosi, 2012). Hence, there are growing concerns about these disposal systems relating to leaching and release of hazardous chemicals (Miller, 2005, Dubaish and Liebezeitm 2013). Wood Plastic Composites (WPC) are composite materials formed by combining two or more components, combined as a macroscopic structural unit with one component as polymer matrix (thermoplastics) and the other as fillers or reinforcements (wood sawdust) (Smith and Wolcott, 2006). Normally, the matrix is the material that holds the reinforcements together and has lower strength than the reinforcements. In the WPC industry, virgin plastics are commonly used. Similarly, recycled plastics with a melting point less than the degradation temperature $200^{\circ} \mathrm{C}$ are also appropriate for manufacturing such composites (Najafi et al., 2007). Commonly used thermoplastics for production of WPCs include polyethylene, polypropylene, and polyvinyl chloride (Panthapulakkal et al., 2006; Yadav and Yusoh 2015).

However, polyethylene is considered the most used thermoplastic material in the manufacturing of WPCs because of its high percentage volume within the amounts of waste and its high resistance to atmospheric and biological agents (Youssef et al. 2019). The use of recycled waste 
(thermoplastics) improves the efficiency of the production process by decreasing imports of virgin thermoplastics and contributes to mitigation of the environmental pollution caused by such waste (Soccalingamea et al., 2015). More research attention is now focused on WPC as preferred building material (Adhikary et al., 2008) in the industrial sectors based on favorable advantages over solid wood including affordability, recyclability, renewability, low density, ability to be shaped into different designs, outdoor application, environmental friendly, non-toxic and desirable mechanical properties (Bengtsson and Oksman 2006, Zhang et al., 2012). Applications of WPC include its use for decking, roof tiles, window trims, automotive parts, stepping stones, and many others (Panthapulakkal et al., 2006). Wood plastic composite popularity and prevalence in markets and construction industries for various purposes is due to the product's perceived low maintenance and environmental performance together with the absence of toxic materials compared to even solid wood treated chemically.

Several studies have been carried out to recycle post-consumer High Density Polyethylene (HDPE) to minimize the environmental impacts in addition to minimizing the use of virgin HDPE (Najafi et al., 2007, Nourbakhsh and Ashori 2009, Kajaks et al., 2017). Yet, studies on WPCs produced from recycled low density polyethylene (Water sachets) which are highly available at very cheap or no cost are still scare. Hence, there is an increasing need to recycle LDPE materials for the production of value added products to compromise the use of virgin materials which will result in less accumulation in landfills and reduce emission of greenhouse gases over a product's life cycle (Akhator et al., 2017). Consequently, this study investigated the water absorption, thickness swelling and strength properties of plastic bonded composites produced from the sawdust of three wood species and Low Density polyethylene (LDPE).

\section{MATERIALS AND METHOD}

\section{Preparation of materials}

Sawdust particles of Triplochiton scleroxylon and Terminalia superba and Gmelina arborea wood species were collected from the Department of Forest Products Development and Utilization, the Forestry Research Institute of Nigeria (FRIN), Ibadan, Oyo State of Nigeria where CD-6 Band saw was used. The sawdust from the three wood species were air-dried separately before each was screened using a sieve of aperture $1 \mathrm{~mm}$ to remove stones and wood particles larger than the predetermined dimension. The sawdust particles were oven dried at the temperature of $103 \pm 2{ }^{\circ} \mathrm{C}$ for 24 hours to reduce its moisture content to about $12 \%$ to aid its bonding with the polyethylene binder (water sachets). The Low Density Polyethylene (LDPE) employed was water sachet used to package drinking water due to its high level of availability in dumping sites at FRIN. The sachet bags were cleaned before shredding into particle form and then air dried to reduce moisture content and ease bonding with the wood particle.

\section{Composite Board Production}

The board formation was based on 60:40 mixing proportion (plastic/wood fiber) weight by weight basis, $1000 \mathrm{~kg} / \mathrm{m}^{3}$ density. The wood and plastic particles were fed into single screw extruders within the temperature range of $80-120^{\circ} \mathrm{C}$ to produce molten compounded WPCs strands. The molten compounded WPCs strands extruded were allowed to pass through water bath to solidify, the solidified WPCs strands were pelletized into grains for molding. WPC samples of 200 $\mathrm{mm} \times 200 \mathrm{~mm} \times 6.4 \mathrm{~mm}$ were produced with the aid of injection moulding machine at a temperature of $140^{\circ} \mathrm{C}$ to $160^{\circ} \mathrm{C}$. The mould was place in a hot-press at temperature $190^{\circ} \mathrm{C}$ and pressed for 8 minutes. The boards were then demoulded, conditioned to cool and cut into $50 \mathrm{~mm} \times 50 \mathrm{~mm}$ sizes for determination of physical properties and for the flexural properties in accordance with standard procedures of ASTM D7031 (2011).

\section{Properties of Determination}

Dimensional Stability: Water Absorption (\%) and Thickness Swelling (\%)

The tests for Water absorption and Thickness swelling were conducted in accordance with ASTM D570 -98. The test specimens of dimension $(50.0 \times 50.0 \times 6.4) \mathrm{mm}$ were air-dried for $24 \mathrm{hrs}$ at room temperature. Then, the width, length, and thickness of each specimen were measured before immersion in water. The specimen were totally submerged in distilled water at room temperature of $26 \pm 2{ }^{\circ} \mathrm{C}$. Measurement of weight and thickness of the composite samples were recorded after soaking in water for 24 hours and 48 hours' time intervals. After Water immersion treatment, the specimens were suspended for 10 min to drain off water. The Water absorption and Thickness swelling of the boards was calculated using equation 1 and 2 below;

$\mathrm{WA}(\%)=\frac{W 2-W 1}{W 1} \times 100$

Where WA $=$ Water Absorption (\%), $\mathrm{W}_{1}=$ Initial Weight $(\mathrm{g})$ and $\mathrm{W}_{2}=$ Final Weight $(\mathrm{g})$

$\operatorname{TS}(\%)=\frac{\mathrm{T} 2-\mathrm{T} 1}{\mathrm{~T} 1} X 100$

Where TS $=$ Thickness swelling $(\%), \mathrm{T}_{1}=$ Initial thickness of the board $(\mathrm{mm})$ before immersion, $\mathrm{T}_{2}=$ Thickness of the board after water immersion $(\mathrm{mm})$.

\section{Tensile Strength}

The tensile strength property of the composite samples was determined using a Universal Testing Machine of model WDW 5000 (UTM- 810 load frame with $50 \mathrm{kN}$ load cell) at a crosshead speed of $20 \mathrm{~mm} / \mathrm{min}$ and lower support of $100 \mathrm{~mm}$. Elongation (strain) of the specimen was measured over $25 \mathrm{~mm}$ gauge length using an extensometer. These were done under ambient conditions of $23 \pm 2^{\circ} \mathrm{C}$ and $50 \%$ relative humidity in accordance with ASTM D1037 (2014). The tensile strength was calculated by dividing the maximum load (Newton) by the original minimum cross-sectional area $\left(\mathrm{m}^{2}\right)$ of the specimen. The young's modulus of elasticity (MOE) was calculated from the load-elongation curves by using the initial linear part. The MOE is equal to the stress increase over this linear period divided by the corresponding increase in the strain.

Tensile strength $=\frac{\text { MaximumLoad }(N)}{\text { CrosssectionalArea }\left(m^{2}\right)}$ 


\section{Experimental Design}

The experimental design adopted was Completely Randomized Design (CRD) involving three varying wood species particles subjected to the same plastic/wood particles mixing proportion (60:40) and uniform density of $1000 \mathrm{~kg} / \mathrm{m}^{3}$ replicated five times. Data obtained were subjected to One-way Analysis of Variance and Duncan Multiple Range follow up test for significant variables. The main factor considered in this study was the wood species (T. superba, T. scleroxylon, and $G$. arborea).

\section{RESULTS}

Table 1: Mean values of water swelling, Thickness Swelling and strength

\begin{tabular}{|c|c|c|c|c|c|}
\hline Composite Content & WA \%(24 hrs) & WA \%(48 hrs) & T S \%(24 hrs) & TS \%(48 hrs) & $\begin{array}{l}\text { Tensile } \\
\text { strength\% }\end{array}$ \\
\hline Gmelina + plastic & $13.15 \pm 0.025$ & $13.28 \pm 0.075$ & $5.54 \pm 0.01$ & $5.58 \pm 0.03$ & $0.44 \pm 0.04$ \\
\hline Triplochiton + plastic & $10.08 \pm 0.22$ & $10.11 \pm 0.20$ & $4.33 \pm 0.05$ & $4.34 \pm 0.05$ & $0.45 \pm 0.07$ \\
\hline Terminalia + plastic & $15.03 \pm 0.01$ & $15.06 \pm 0.00$ & $5.52 \pm 0.23$ & $5.54 \pm 0.24$ & $0.29 \pm 0.04$ \\
\hline
\end{tabular}

Means having different superscript on the table are significantly different $(p<0.05)$

Table 2: Analysis of Variance table for Water Absorption

\begin{tabular}{lcccccc}
\hline \multicolumn{1}{c}{$\begin{array}{c}\text { Source of } \\
\text { Variation }\end{array}$} & SS & df & MS & F & P-value & F crit \\
\hline Wood Species & 37.47375 & 2 & 18.73688 & 7700.086 & $6.74 \mathrm{E}-08$ & 6.944272 \\
Water absorption & 0.024067 & 2 & 0.012033 & 4.945205 & 0.082926 & 6.944272 \\
Error & 0.009733 & 4 & 0.002433 & & & \\
\hline
\end{tabular}

Table 3: Analysis of Variance table for Thickness Swelling

\begin{tabular}{lcccccc}
\hline \multicolumn{1}{c}{ Source of Variation } & SS & df & MS & F & P-value & F crit \\
\hline Wood Species & 2.190104 & 2 & 1.095052 & 5776.099 & $1.2 \mathrm{E}-07$ & 6.944272 \\
Thickness swelling & 0.004163 & 2 & 0.002081 & 10.97802 & 0.023749 & 6.944272 \\
Error & 0.000758 & 4 & 0.00019 & & & \\
\hline
\end{tabular}

Table 4: Analysis of Variance table for Tensile Strength

\begin{tabular}{lcccccc}
\hline \multicolumn{1}{c}{ Source of Variation } & SS & df & MS & F & P-value & F crit \\
\hline Wood Species & 0.047213 & 2 & 0.023606 & 2.800978 & 0.138312 & 5.143253 \\
Error & 0.050567 & 6 & 0.008428 & & & \\
\hline
\end{tabular}
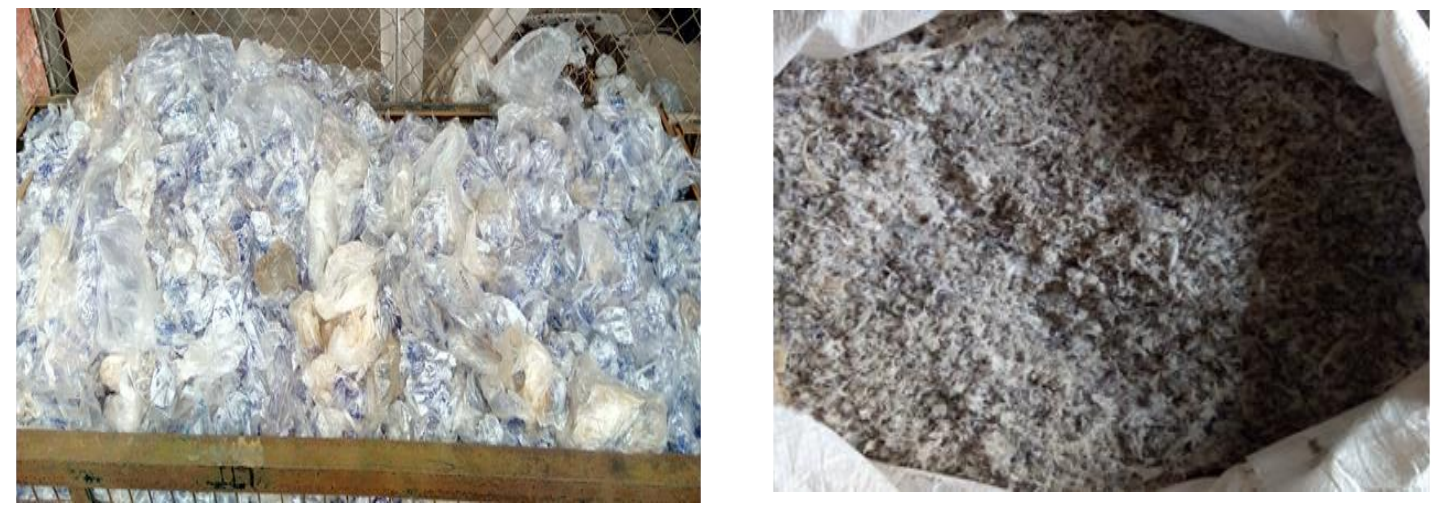

Plate 1: LDPE (Water Sachets) before and after milling 


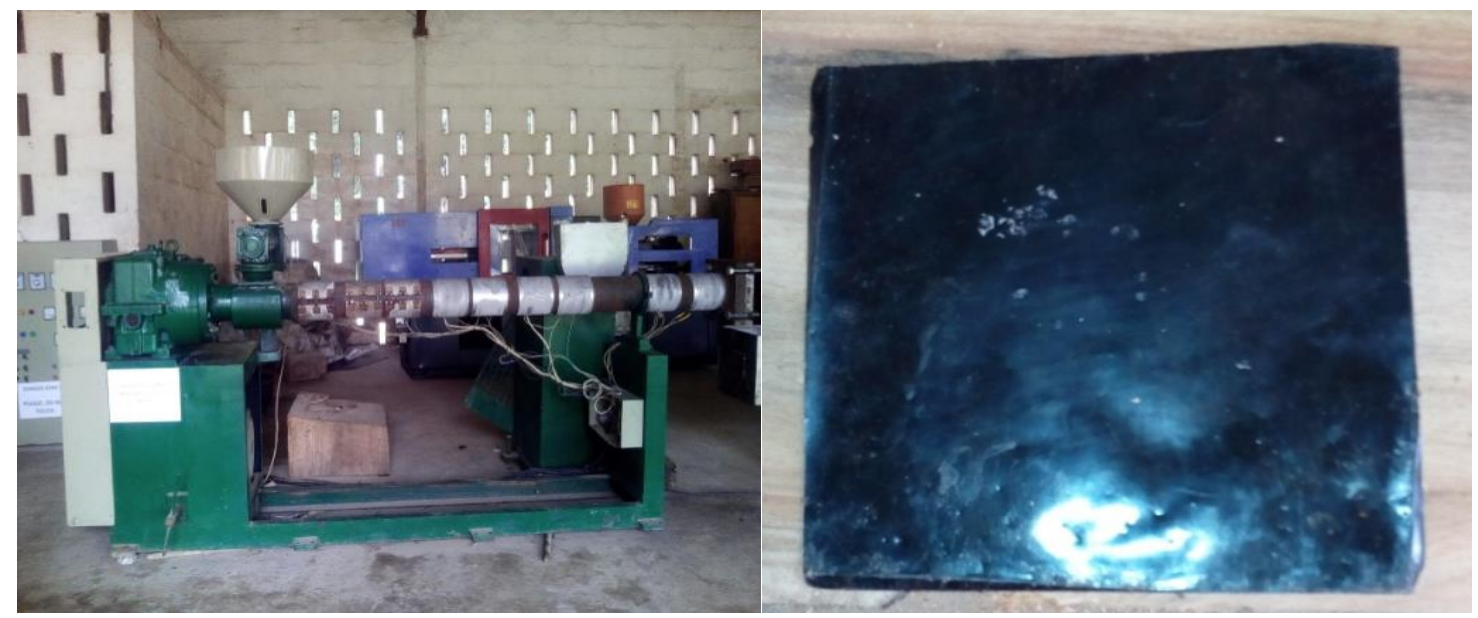

Plate 2: Extruding machine and WPC board

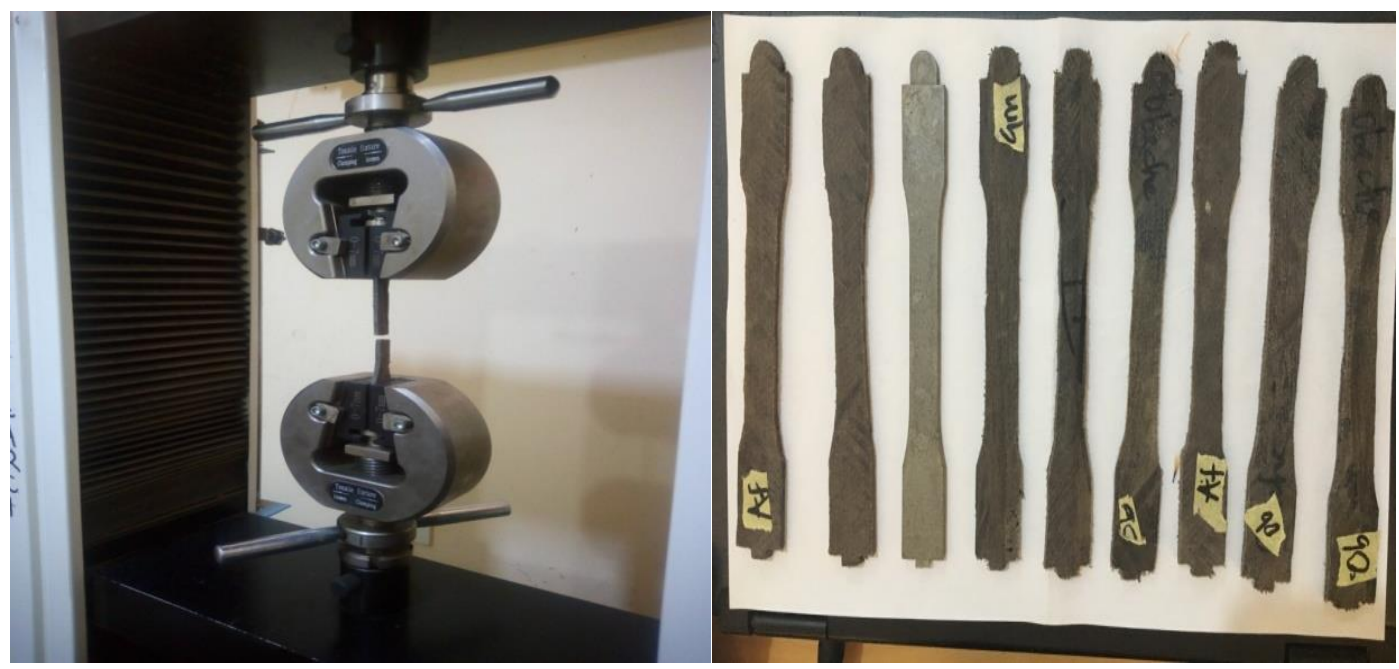

Plate 3: Flexural Resistance of the Composite Board Sample

\section{DISCUSSION}

Dimensional Stability: Water Absorption and Thickness Swelling

The outcomes of descriptive statistics, analysis of variance for the assessment of dimensional properties are presented in Table 1 below. The effects of wood species in the presence of higher plastic proportion to dimensional properties of the WPCs from the varying wood species were discussed. The outcome of average values obtained of water absorption ranged from $10.08 \%$ to $15.03 \%$ after $24 \mathrm{hr}$ immersion in water and $10.21 \%$ to $15.36 \%$ after 48 hrs immersion in water as shown in Table 1 while the thickness swelling of the composite boards ranged from $4.33 \%$ to $5.58 \%$ as shown in Table 1 also which implies that properties of wood species employed during the production of WPCs influence the dimensional properties. The capacity to absorption water agrees with Obada et al., (2018), the alignment of the lignocellulosic and hydrophilic wood fibers led to the water uptake of the composite. This is due to formation of hydrogen bonds with water molecules. Furthermore, it was observed that composites made from Triplochiton scleroxylon wood particles had the highest water uptake consecutively followed by composite made from
Gmelina arborea and Terminalia superba particles. This trend may be attributed to varying density of each wood species as reported by Carsan et al. (2012). The density of Triplochiton scleroxylon, Gmelina arborea and Terminalia superba wood species were $0.49 \mathrm{~g} / \mathrm{m}^{3}, 0.56 \mathrm{~g} / \mathrm{m}^{3}$ and $0.72 \mathrm{~g} / \mathrm{m}^{3}$ respectively. Based on the result and as similarly reiterated by Klyosov (2007), high density wood species tend to exhibit lower water absorption rate. Terminalia superba wood species having the highest wood density exhibited the lowest water absorption capacity in the composite board, while Triplochiton scleroxylon wood species with the lowest density displayed the highest water uptake in the composite board, even after encapsulation with plastic fillers. This can be attributed to the fact that high density wood species contain tightly-packed fibre cells with heavily lignified cells walls and little or no air spaces. It was observed that composite produced from Triplochiton scleroxylon wood wastes had the highest retention of water after 24 hours soaking in water, followed by composite made with Gmelina arborea particles, while composite made with Terminalia superba composite had the lowest absorbed water after 24 hours soaking in water. The same trend was also observed for composites immersed in water for 48 hours. The 
result presented in Table 2 and 3 also reported significant differences between the three wood species particles used for the composite production. As similarly observed for water absorption, the thickness swelling of the composite board was lowest for boards produced from Terminalia superba particles, while composite boards produced from Gmelina arborea and Triplochiton scleroxylon particles had the highest thickness swelling for both $24 \mathrm{hrs}$ and $48 \mathrm{hrs}$ soaking in water as presented in Table 3. The thickness swelling of the composite boards ranged from $4.33 \%$ to $5.54 \%$ and $4.34 \%$ to $5.58 \%$ after 24 hours and $48 \mathrm{hrs}$ immersion in water respectively. Composite boards produced from Terminalia superba particles had the lowest significant increase in thickness after 24 hours and $48 \mathrm{hrs}$ water immersion. Low density wood species on the contrary has more air spaces which is responsible for more intake of water into the cell cavities. The implication of this is that the lower water uptake exhibited by the high density Terminalia superba composite board connotes beneficial effect on the lifespan of the wood plastic composite board and on its application properties which agrees to Dányádi et al. (2010). Furthermore, Obada et al. (2018) asserted that the presence of miniaturized scale voids, pores, and micro-cracks on the composite boards could contribute to its water uptake capacity though encapsulated with hydrophobic thermoplastics. The low thickness swelling observed in the composite board can be attributed to the encapsulation of the wood particles with hydrophobic thermoplastics. This gives an indication that water absorption occurs usually in the micro-voids of the composite boards.

\section{Tensile strength}

The tensile strength of the wood composite boards ranged between 29.4 $\mathrm{MPa}$ and $45.6 \mathrm{MPa}$ as shown in Table 4. The effect of the different wood species on the tensile strength of the composite board showed that boards produced from Triplochiton scleroxylon particle had the lowest significant tensile strength, while composite board produced from Terminalia superba particles had the highest flexural strength, followed by boards produced from Gmelina arborea. It was observed that significant differences only existed between boards produced from Triplochiton scleroxylon and boards produced from the remaining two wood species.

The tensile strength of wood plastic composites is usually affected by the filler fraction and the interfacial adhesion between particles and matrix (Sun et al., 2006). This kind of behavior may be attributed to better interfacial adhesion between the matrix and the wood fibers (Yadav \& Yusoh 2015). The effect of wood species on tensile strength of the composite board indicated that composite board made with Terminalia superba wood species particles had the highest tensile strength followed by Gmelina arborea composite board, while Triplochiton scleroxylon composite board had the least tensile strength. This observed inference might be attributed to the fact that the high density wood species possesses high interfacial area for better mechanical interlocking with the matrix (Green et al. 1999) and less void contents (Gacitua and Wolcott 2009). This implies that high density of Terminalia superba wood species compared to that of Gmelina arborea and Triplochiton scleroxylon contributes to better dispersion of the hydrophilic particles into the hydrophobic thermoplastic matrix and reduced stress concentration which is in line with (Ratnam et al. 2010; Atuanya et al. 2013). As earlier asserted, the
Triplochiton scleroxylon wood species has more hydroxyl groups thus preventing good adhesion between the wood particle and the plastic matrix which consequently reduce the tensile strength of the composite board. The lower density and higher void content in the Triplochiton scleroxylon composite board resulted in its lower tensile strength property as voids do not transmit stresses, leading to stress concentration. This observed inferences are in collaboration with the findings of Gacitua and Wolcott (2009), who established that wood with smaller voids size area tend to have high tensile strength and vice versa.

\section{CONCLUSION}

The study showed that WPC can be successful produced from recycled Low Density Polyethylene and particles from different wood species. The results also showed that even when higher plastic content are considered, properties of wood species should be equally put into consideration as variation occur in the dimensional properties and strength properties of the WPC at equal plastic content. This research study shows that Terminalia superba which possess the highest density demonstrated lowest water absorption and highest strength property.

\section{REFERENCES}

Adhikary, K.B., Shusheng, P. and Mark, P.S. 2008. Dimensional stability and mechanical behaviour of woodplastic composites based on recycled and virgin high-density polyethelene (HDPE). Composites: Part B 39:807-815.

Akhator, P., Obanor, A. \& Ugege, A. 2017. Nigerian Wood Waste: A potential resource for economic development. Journal of Applied Sciences and Environmental Management. 21: $246-251$.

Alabi, O.A, Ologbonjaye, K.I., Awosolu, O. \& Alalade, O.E. 2019. Public and environmental health effects of plastic wastes disposal: A Review. J Toxicol Risk Assess 5: 021.

ASTM D7031-11. 2011. Standard Guide for Evaluating Mechanical and Physical Properties of Wood-Plastic Composite Products, ASTM International, West Conshohocken, PA.

ASTM D1037-14. 2014. Standard test methods for evaluating properties of wood-base fiber and particle panel materials. ASTM International. West Conshohocken, PA.

Atuanya, C.U., Olaitan, S.A., Azeez, T.O., Akagu, C.C., Onukwuli, O.D.\& Menkiti, M.C. 2013. Effect of rice husk filler on mechanical properties of polyethylene matrix composite. Int J Cur Res Rev 5:111-118

Bengtsson, M.\& Oksman, K. 2006. Silane crosslinked wood plastic composites: Processing and properties. Composites Science and Technology 66: 2177-2186.

Carsan, S., Orwa, C., Harwood, C., Kindt, R., Stroebel, A., Neufeldt, H.\& Jamnadass, R.. 2012. African Wood Density Database. World Agroforestry Centre, Nairobi. 
Dányádi, L., Móczó, J.\& Pukánszky, B. 2010. Effect of various surface modifications of wood flour on the properties of PP and wood composites. Composites Part A 41(2):199-206.

Dubaish, F.\& Liebezeit,G. 2013. Suspended microplastics and black carbon particles in the Jade System, Southern North Sea. Water Air Soil Pollut 224(2): 1352

Gacitua, W.\& Wolcott,M. 2009. Morphology of wood species affecting wood-thermoplastic interaction: microstructure and mechanical adhesion. Maderas. Ciencia y technologia 11: 217 231.

Geyer, R., Jambeck, J.R.\& Law, K.L. 2017. Production, use, and fate of all plastics ever made. Sci. Adv 3(7), e1700782.

Green, D.W., Winandy, Je and Kretschmann De. 1999. Mechanical properties of wood. From Forest Products Laboratory. 1999. Wood handbook—Wood as an engineering material. Gen. Tech. Rep. FPL-GTR-113. Madison. Department of Agriculture, Forest Service, Forest Products Laboratory. $463 \mathrm{p}$.

Kajaks, J., Kalnins, K.\& Naburgs, R. 2017. Wood plastic composites (WPC) based on high-density polyethylene and birch wood plywood production residues. International Wood Products Journal. 9: 15-21.

Klyosov,A. A. 2007. Wood-Plastic Composites. John Wiley and Sons, Inc, Hoboken.

Miller, R. 2005. The landscape for biopolymers in packaging Miller-Klein Associates report. Summary and Full Report available from The National Non-Food Crops Centre, Heslington.

Najafi, K.S., Tajvidi, M. \& Hamidina, E. 2007. Effect of temperature, plastic type and virginity on the water uptake of sawdust/plastic composites. Holz als Roh - und Werkstoff 65: 377-382

Nourbakhsh, A. \& Ashori,A. 2009. Preparation and properties of wood plastic composites made of recycled High-density Polyethylene. Journal of Composite Materials 43: 877-883

Obada, D.O., Kuburi, L.S., Dauda, M.et al. 2018. Effect of variation in frequencies on the viscoelastic properties of Coir and Coconut husk powder reinforced polymer composites. Journal of King Saud University - Engineering Sciences.

Ogunwusi,A.A. 2014. Wood Waste Generation in the Forest Industry in Nigeria and Prospects for its Industrial Utilization. Civil and Environmental Research 6: 62-69
Olufemi, A, Sotande, A.O., Oluwadare, O.O.\& Paul, F. 2012. Evaluation of cement-bonded board produced from Afzelia africana wood residues. Journal of Engineering Science and Technology 7: 732-743.

Panthapulakkal, S., Zereshkian, A.\& Sain,M. 2006. Preparation and characterization of wheat straw fibers for reinforcing application in injection molded thermoplastic composites. Bioresource Technology 97: 265-272.

Pianosi, M. 2012. Sustainable waste management. Available at https://torinobyveg.wordpress.com/2012/11/19/sustainablewast esustainablewastemanagement (Accessed on September/06/2018)

Ratnam, C.T., Fazlina, R.S.\& Shamsuddin,V. 2010. Mechanical properties of rubber-wood fiber filled PVC/ENR blend. Malaysian Polymer Journal. 5: 17-25.

Smith, P.M.\&Wolcott, M.P. 2006. Opportunities for wood and natural Fiber-Plastic Composites in residential and industrial applications. Forest Products Journal 56: 4-11.

Soccalingamea, L., Bourmaudb, A., Perrina, D., Benezeta, J.C., \&Bergereta, A. 2015. Reprocessing of wood flour reinforced polypropylene composites: Impact of particle size and coupling agent on composite and particle properties. Polym. Degrad. Stab $113,72 \mathrm{e} 85$.

Sun, S., Li, C., Zhang, L., Du, H.\&Burnell-Gray, J.S. 2006. Interfacial structures and mechanical properties of PVC composites reinforced by $\mathrm{CaCO}_{3}$ with different particle sizes and surface treatments. Polymer International 55:158-164.

United Nations. 2018. Beat Plastic Pollution. Our planet is drowning in plastic pollution. Accessed on the $23^{\text {rd }}$ of June 2019 from https://www.unenvironment.org/interactive/beatplastic-pollution/

Yadav, S. M \&Yusoh, K.B. 2015. Mechanical and Physical Properties of Wood-Plastic Composites made of Polypropylene, Wood Flour and Nanoclay. Pp 1-10 Proceeding - Kuala Lumpur International Agriculture, Forestry and Plantation September 12 - 13, 2015. Kuala Lumpur.

Youssef, P., Zahran, K., Khaled Nassar, K.M., Darwish, M. \& El Haggar, S. 2019. Manufacturing of Wood-Plastic Composite boards and their mechanical and structural characteristics. Journal of Materials in Civil Engineering 31(10): 04019232.

Zhang, W.F., Wang, G., Cheng, H.T., Lin, L.M.\& Qiu, Y.X. 2012. Effects of lay-up structure on physical and mechanical properties of laminated bamboo bundle board. Journal of Central South University of Forestry \& Technology 32: 147150.

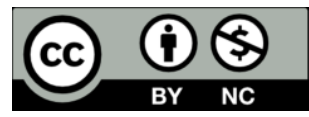

C2020 This is an Open Access article distributed under the terms of the Creative Commons Attribution 4.0 International license viewed via https://creativecommons.org/licenses/by/4.0/ which permits unrestricted use, distribution, and reproduction in any medium, provided the original work is cited appropriately. 